\title{
SEABATHER'S ERUPTION: A CLINICAL AND EPIDEMIOLOGICAL STUDY OF 38 CASES IN SANTA CATARINA STATE, BRAZIL
}

André Luiz ROSSETTO(1), Gerson DELLATORRE(1), Fábio Lang da SILVEIRA(2) \& Vidal HADDAD JÚNIOR(3,4)

\begin{abstract}
SUMMARY
Seabather's eruption (SBE) is an intensely itchy, papule-erythematous dermatitis that occurs predominantly in regions of the body covered by bathing costumes, after exposure to marine water. The planulae larvae of Linuche unguiculata scyphomedusae (thimble jellyfish) are the etiologic agent of the dermatitis, which is frequent in waters of Caribbean, Gulf of Mexico and Florida. The authors report 38 cases of SBE in the State of Santa Catarina (Southern region of Brazil), with emphasis on their clinical and epidemiological aspects, such as profile of victim, topography of the papules and conditions predisposing to the accident.
\end{abstract}

KEYWORDS: Dermatitis; Linuche unguiculata; Cnidaria; Venomous marine animals, Brazil; Seabather's eruption.

\section{INTRODUCTION}

Seabather's eruption (SBE) is a papule-erythematous dermatitis intensely itchy, which occurs in regions of the body covered by bathing costumes, and regions of skin folds after exposure to marine water ${ }^{6,9,13,20,22}$. The first descriptions of the disease occurred in 1903, in Florida, United States, by an unknown citizen and in 1939, as medical report, by Thomas ${ }^{9,20,22}$. HADDAD Jr. et al. described the first cases of the disease observed in Brazil in $2001^{9}$ and ROSSETTO et al. described additional cases in South region in $2007^{22}$.

WILLIAMSON et al. cited various marine organisms as causing the $\mathrm{SBE}^{28}$. BLACK et al. in 1994 indicated for the first time the planulae larvae of the scyphomedusae Linuche unguiculata as the probable etiologic agent of dermatitis ${ }^{1}$. This small jellyfish, with a size around 1.5 $\mathrm{cm}$ in diameter, is common in the waters of the Caribbean (Belize, Cuba, Mexico), Gulf of Mexico and tropical North Atlantic West (Florida, Cuba and Bahamas), with numerous reports of the disease in those regions, which reaches epidemic proportions ${ }^{9,20,22}$. The planulae larvae of Linuche unguiculata measure approximately $0.5 \mathrm{~mm}$ and are small enough to pass through the mesh of swimwear ${ }^{16}$. When the bather leaves the water, the suit acts as a filter, draining the water and imprisoning the larvae against the skin, activating the defense mechanism of these jellyfish causing envenomation ${ }^{13,20}$.

The discharge of toxins is done by organelles called nematocysts, formed by a dense capsule with a tubular structure, harpoon-like, containing the toxins. Briefly before the envenomation, the inside of the capsule reaches a pressure of approximately $150 \mathrm{~atm}$, releasing the harpoon, which penetrates the human skin, discharging its contents at a fraction of seconds ${ }^{10,11,16,19}$. The contact with freshwater or osmotic pressure change can trigger the process ${ }^{9,13.16}$. PUERTAS et al. described that the three stages of the life cycle of L. unguiculata, planulae, ephyra, and adult jellyfish, can cause SBE, differing clinically according to the morphology of the skin lesion and the time of the year ${ }^{20}$.

The typical clinical manifestations are characterized by the presence of an papule-erythematous eruption which is highly pruriginous and similar to insect bites, appearing soon after an ocean exposure, specially in areas covered by the swimwear, with gradual increase in pruritus intensity $8,9,13,22,29$. Systemic symptoms such as fever, chills, nausea, vomiting, headache, abdominal pain and diarrhea are seen occasionally and generally occur in children or with severe envenomation ${ }^{2,13,29}$.

The SBE is different than swimmer's itch, which has a worldwide distribution and usually occurs after bathing in freshwater. Swimmer's itch is limited to exposed areas of the body and the agents responsible are the cercariae of Schistosoma spp. ${ }^{29}$. For swimmer's itch, the other main differential diagnoses are the insect bites and scabies ${ }^{9,22,26}$.

The histological aspect on biopsy is not distinct, but biopsy can be useful in the differential diagnosis, revealing the presence of superficial and deep interstitial and perivascular infiltrate, consisting of lymphocytes, neutrophils and eosinophils ${ }^{29}$. The toxins of cnidarians are composed of a complex mixture of peptides and enzymes that are at the same time, toxic and antigenic to human beings ${ }^{4}$. The technique of ELISA (enzyme-linked immunosorbent assay) allows the demonstration of specific reactivity with the class $\mathrm{IgG}$ antibodies to L. unguiculata in the serum of affected 
ROSSETTO, A.L.; DELLATORRE, G.; SILVEIRA, F.L. \& HADDAD JÚNIOR, V. - Seabather's eruption: a clinical and epidemiological study of 38 cases in Santa Catarina State, Brazil. Rev. Inst. Med. trop. S. Paulo, 51(3): 169-175, 2009.

people ${ }^{5,29}$. The initial treatment, at the time of exposure, involves the prompt removal of swimwear, once out of the water and can thus limit the skin $\operatorname{rash}^{29}$.

Treatment after the first measures is based on the use of lotions, oral antihistamines, topical corticosteroids and, in severe cases, oral corticosteroid, with good results in local symptoms ${ }^{8,9}$. SBE is a selflimited process with the dermatitis having spontaneous resolution generally in one week but can last for up to two weeks ${ }^{9,22}$.

\section{OBJECTIVES}

We evaluated and measured the SBE occurrence, alerting for a new risk factor for the bathers along the coast of Santa Catarina State, Southern Region of Brazil.

\section{MATERIAL AND METHODS}

A retrospective study was conducted on 16,222 archived observations of patients of a dermatologic private clinic in the Balneário Camboriú Town (26 59' 26'S $\left.48^{\circ} 38^{\prime} 05^{\prime \prime} \mathrm{W}\right)$, located in central-northern coast of Santa Catarina State, Southern Region of Brazil, from January, 2001 to December, 2007. The sources of information were patients with clinical diagnosis of SBE, complemented with data recorded on a protocol of accidents by cnidarians. We noted the following variables: identity, age, sex, date of the accident, number of episodes, date of diagnosis; elapsed time (in days) date of exposure until the clinical diagnosis of SBE; time of the beginning of the sea bath; time (in hours) remained in the beach; usual or non-usual visitor of the beach of exposure; behalf of the beach and the municipality of exposure; record of the presence of jellyfish in water or sand; knowledge of the presence of other casualties; onset of symptoms; presence of systemic symptoms and treatment.

Serum of patients was collected (if allowed) for future serologic test and a skin biopsy was done whenever possible for histological examination

\section{RESULTS}

We found thirty-eight cases $(0.23 \%)$ with clinical diagnosis of SBE, all the exposures observed in the central-northern coast of the Santa Catarina State. Most of the victims were from the region of exposures $(84 \%)$ and six patients were tourists $(16 \%)$.

The SBE cases were recorded in twelve different beaches of six municipalities. In those beaches, the exposures occurred more frequently on the beach of Balneário Camboriú (44.7\%), followed by Brava (13.2\%), Laranjeiras (10.6\%), Zimbros (7.9\%), Atalaia (5.3\%) and the other seven beaches (Armação, Cabeçudas, Canto Grande, Caixa D’Aço, Mariscal, Quilombo and São Miguel) with one case (2.6\%) in each beach (Fig. 1).

The year with the highest rate of diagnosis was $2006(52.6 \%)$, followed by 2005 (15.8\%), 2001 (13.2\%), 2004 (10.5\%) and 2007 (7.9\%). There was no recorded case in the years 2002 and 2003.

As for the four seasons of the year, the accidents often occurred in the spring and summer, both with 16 cases $(42.1 \%)$, followed by autumn

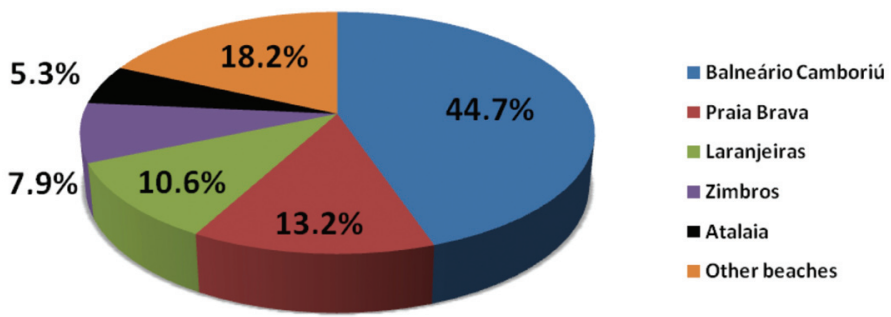

Fig. 1 - Distribution of the 38 cases by the twelve Santa Catarina beaches * Armação, Cabeçudas, Canto Grande, Mariscal, Caixa D’Aço, Quilombo, São Miguel (each beach presented one case: $2.6 \%$ ).

$(13.2 \%)$ and winter $(2.6 \%)$. As for the months of the year, accidents often occurred in December (39.5\%), followed by January (36.7\%), May $(5.3 \%)$ and the other months (February, March, April, June, September, October and November) with one case $(2.6 \%)$ in each of seven months. There were no case records in July and August.

The disease affected 21 men (55.3\%) and seventeen females (44.7\%). The age of patients ranged from two to 60 years, with an average of 17.5 years, and a median of 12.5 years. Most of the casualties were children and young people under the age of sixteen years (60.5\%) (Fig. 2). Among the thirty-eight cases, fifteen were surfers $(39.5 \%)$.

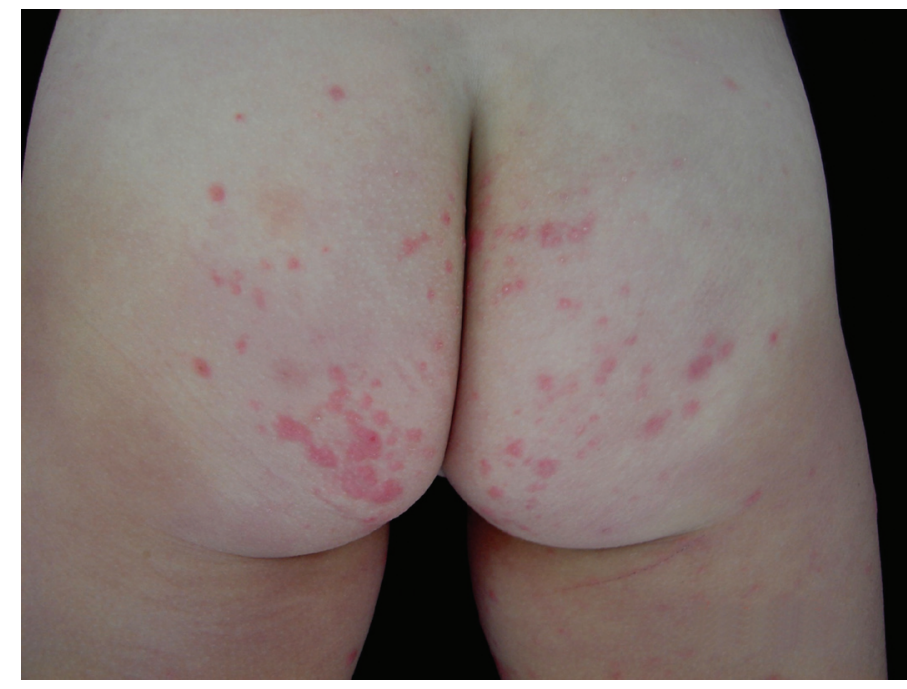

Fig. 2 - First episode of SBE in a three year old female child, non-usual visitor of Laranjeiras Beach (municipality of Balneário Camboriú, State of Santa Catarina). Detail of the erythematous and highly itchy papules located at the gluteal region and restricted to areas covered by the bathing costumes.

In 13 patients (34.2\%) symptoms occurred among other seabather's in their group. The possible exposures reported by these patients occurred, mostly in the beach of Balneário Camboriú (76.9\%), followed by Mariscal, Zimbros and Brava, all with one record (7.7\%). Though symptoms occurred in others, they did not seek medication care at the clinic and are not included.

The presence of jellyfish was reported by ten patients $(26.3 \%)$. However, the majority $(70 \%)$ were unable to identify the species of 


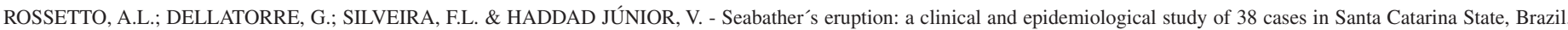
Rev. Inst. Med. trop. S. Paulo, 51(3): 169-175, 2009.

jellyfish found at the site of the accident, and three patients (30\%) recognized the shape of the adult medusa of $L$. unguiculata from a photo shown at the time of consultation. The jellyfish were observed either in the water or on the beach of Balneário Camboriú (40\%), Brava (30\%), Zimbros (20\%) and Laranjeiras (10\%).

A large amount of green algae, not identified, was found in eight patients $(21.1 \%)$, with the majority on the beach of Balneário Camboriú $(87.5 \%)$ and Cabeçudas (12.5\%). One patient (2.6\%) noted the presence of transparent algae on the sand on the beach of Atalaia. All nine patients of this group did not observe any jellyfish.

The time elapsed (in days) between the accident until the clinical diagnosis of SBE in most cases was recorded (92.1\%) and in three cases $(7.9 \%)$ was not registered. In the cases recorded, the time ranged from one to fifteen days with an average of 5.8 days and a median of four days.

The time of the arrival on the beach and time in the place, including baths in the sea, in most cases was recorded (84.2\%) and in six cases not registered (15.8\%). In the cases recorded, the time of arrival on the beach ranged from 08 a.m. to 4 p.m. with an average of 11:41 a.m. and a median of 10:30 a.m.

As for the length of permanence on the beach of the accident interspersed with sea baths, it ranged from one to eight hours with an average length of two hours and 53 minutes and a median of two hours and 30 minutes.

It was observed a single episode of SBE in most patients $(78.9 \%)$ (Fig. 3). In eight patients $(21.1 \%)$ occurred more than an accident, being four episodes the maximum number per person. The presence of the second and third episode of SBE, in both, was observed in two cases $(5.3 \%)$. The occurrence of the fourth episode was recorded in four patients $(10.5 \%)$.

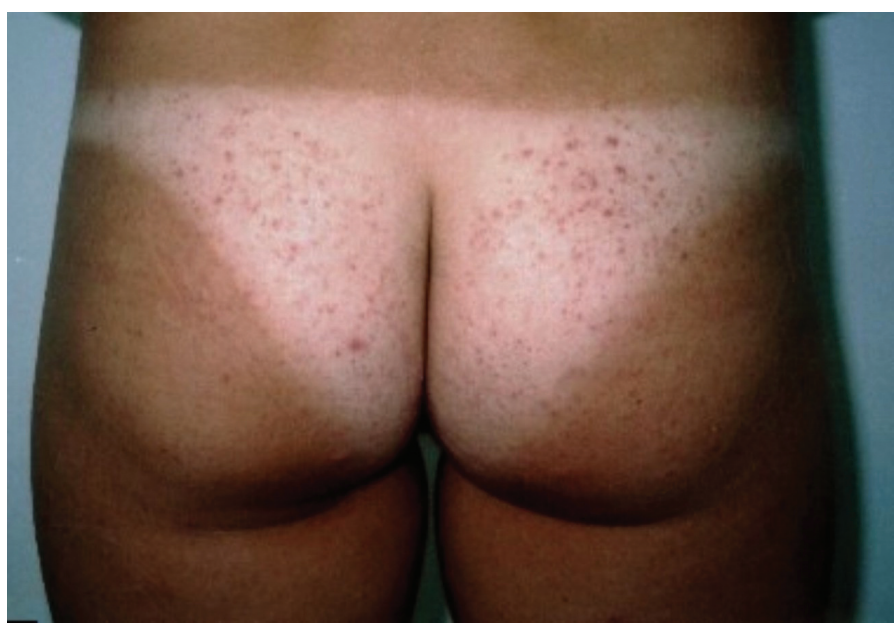

Fig. 3 - A 17 year-old patient, female, frequent visitor of the accident's beach (Balneário Camboriú, State of Santa Catarina), with one episode of SBE, presenting erithematous and itchy papules at the gluteal region, restricted to areas located under the swimwear.

The two patients who had a second episode of SBE were usual visitors to the beach of Balneário Camboriú. One of the victims was a child of four years, tourist, with an interval of 24 hours between the accidents, aggravating further the initial symptoms. The other was a 12 year-old surfer, with a range of eleven months between the accidents.

There were two patients with three episodes of SBE: one was a woman of sixty years, tourist, and frequent visitor of the beaches. The incidents occurred at two months intervals. The other victim was a 24 year-old surfer, frequent user of the beach of Quilombo, with a range of 12 months between the first and second episode and 21 months between the second and the third episode.

For the victims with four episodes, they were all frequent visitors of the beaches of accidents. None of the four patients were tourists, with two being surfers and two being non-surfers. The surfers were 12 and 22 years old, while the range of accidents was, respectively, seven months and ten days. The patients that were not surfers were a 2 year-old child and a 12 year-old adolescent. Intervals of the accidents were, respectively, twenty days and five months.

The most common local symptoms were burning and itching during $(39.5 \%)$ or immediately after the saltwater exposure $(10.5 \%)$ and that gradually increased in intensity during the next $12-24$ hours $(47.4 \%)$. One patient $(2.6 \%)$ cited the onset of the injuries 36 hours after exposure (Fig. 4).

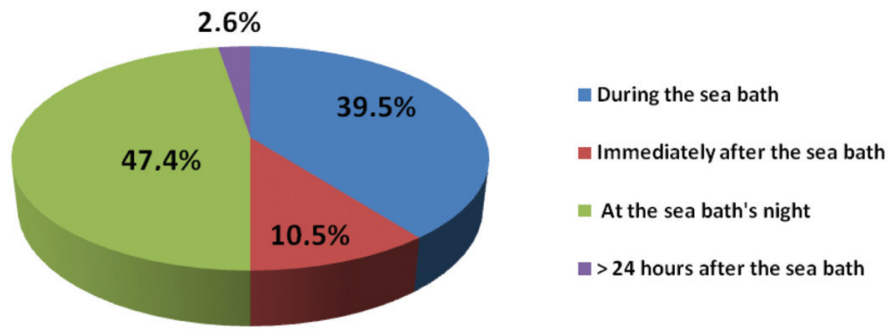

Fig. 4 - Distribution of 38 cases as the onset of symptoms.

Systemic symptoms were relatively uncommon, but dyspnea, malaise and sneezing occurred in three adults (7.9\%). All the patients had erythematous papules. A surfer using neoprene surfing clothes, presented one second episode of SBE with acne-like papules and pustules located on the anterior chest, abdomen, back and shoulders. An adult woman, as the result of the excoriation, presented with pustules and crusting on the right upper limb accompanied by local pain (Fig. 5 and 6).

The location of the injuries occurred in fourteen different anatomical regions: gluteal above pubic, pubic, penis, scrotum, mammary, armpits, superior chest, abdomen, back, neck, arms and legs. Those regions were involved in one hundred and twenty-one times, ranging from two to six regions per patient, with an average of 3.1 regions per patient, with clear predilection for areas covered by swimwear. Thus, clothes common to all patients, such as those used in the hips, showed the highest percentage of injuries (gluteal region, 65.8\% - Fig. 7). In women, the upper chest was also frequently compromised for the characteristics of the female swimwear. In surfers, both the chest and abdomen had involvement in the majority (60.0\%) Lesions on the arms and thighs were frequent only in surfers, located on the areas in contact with the surfboard. In two patients, one male and one female, injuries also occurred in areas at the contour of their bathing costumes. 


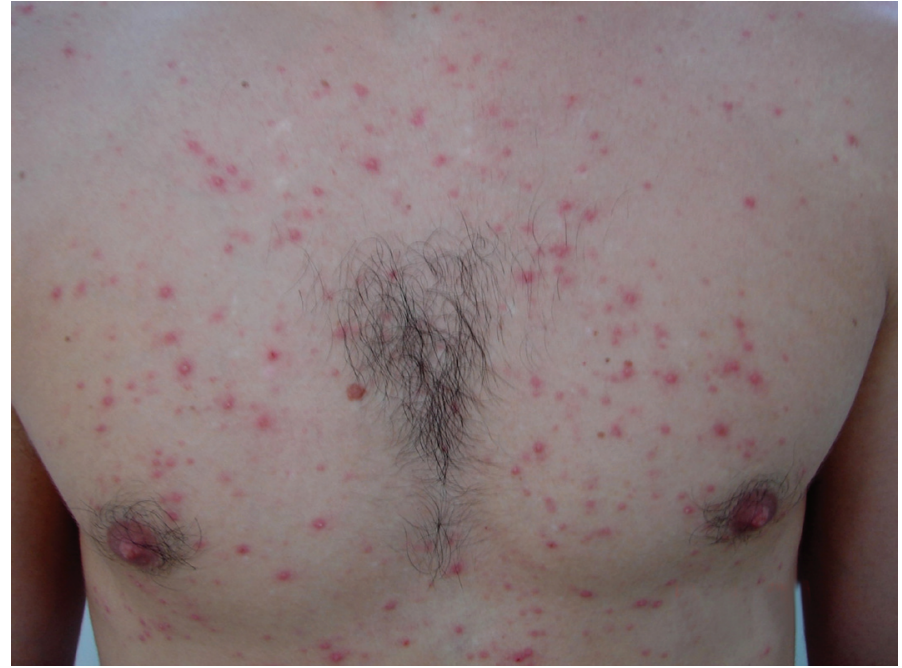

Fig. 5 - A 24 year-old patient, male, surfer, wearing neoprene suit, frequent visitor of Quilombo Beach (Municipality of Penha, State of Santa Catarina), at his second episode of erythematous papules and pustules, which presented as acneform lesions, that also were highly itchy, located at the anterior chest, after surfing.

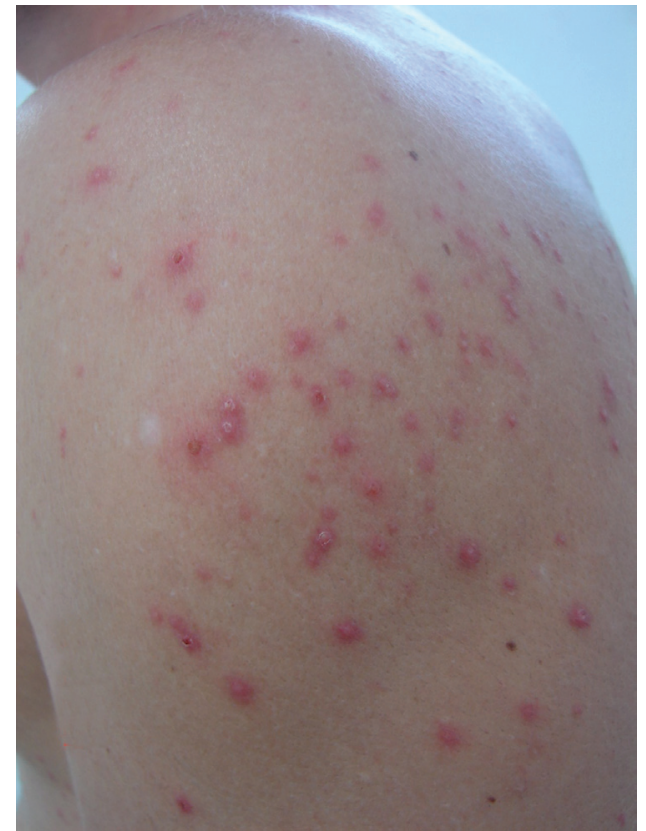

Fig. 6 - Detail of acneform lesions on the left shoulder extending to the back in a surfer wearing neoprene suit, after surfing.

Histological examination occurred in two patients $(5.3 \%)$ in a private laboratory in the Curitiba city, Parana State and the other at the Evandro Chagas Clinical Research Institute (Ipec-FioCruz), in the Rio de Janeiro city. Routine hematoxylin-eosin stain of the skin of the first subject specimen revealed discreet lamellar keratosis, foci of parakeratosis, irregular acanthosis, discreet focal spongiosis and occasional presence of lymphocytes and neutrophils with exocytosis. In the superficial and medium dermis, a moderated inflammatory perivascular infiltrate was evident, predominantly lymphocytic, with areas showing neutrophils

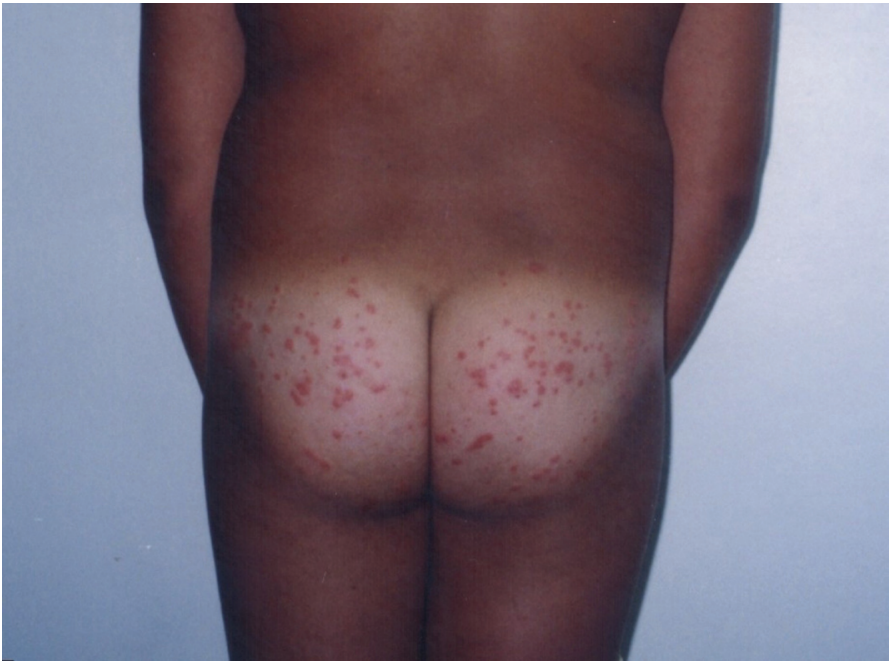

Fig. 7 - A male child, frequent visitor of Balneário Camboriú beach, State of Santa Catarina, with one episode of erithematous papules, intensely itchy, located under the swimwear.

and eosinophils between the collagen. The PAS stain did not reveal other abnormalities. The histopathologic diagnosis was a spongiotic and perivascular dermatitis, with the comment of histological picture compatible with acute prurigo.

The second patient's examination in hematoxylin-eosin staining showed in the epidermis irregular acanthosis and foci of slight spongiosis and apoptosis of keratinocytes in the epidermis. Edema of papillary dermis and lymphocytic perivascular inflammatory infiltrate with occasional neutrophils and eosinophils was also present. In our experience, the histopathologic findings were nonspecific and the primary diagnosis is based on history and physical examination with the distribution of the dermatitis in the context of the swimwear worn.

Currently, due to unavailability of serological tests in Brazil, we collected the serum of twenty-three patients $(60.5 \%)$ for laboratory tests in the future. The serum was stored in a laboratory and under proper refrigeration. A patient got two collections on different dates, three and seventeen days after the first accident.

Therapy: Most patients $(81.6 \%)$ used the antihistamines in combination with systemic and topical steroids. One patient $(2.6 \%)$ used topical hydrocortisone $1 \%$ monotherapy. Six patients $(15.8 \%)$ progressed with spontaneous regression of skin lesions.

Complications were relatively uncommon, but were notable in two patients. In the first, intense excoriation caused secondary bacterial infection. For treatment, the patient required, beyond the dexclorfeniramine $2 \mathrm{mg}$ orally twice daily and ointment hydrocortisone $1 \%$ twice daily and roxithromycin orally $300 \mathrm{mg}$ daily for five days, dipyrone $500 \mathrm{mg}$ orally four times daily and topic chloramphenicol three times daily for 10 days.

In the second, a young surfer, with four episodes of SBE, was refractory to treatment with loratadine and desonide and they required corticosteroid (betamethasone), administered intramuscularly for the regression of the manifestations (Fig. 8). 


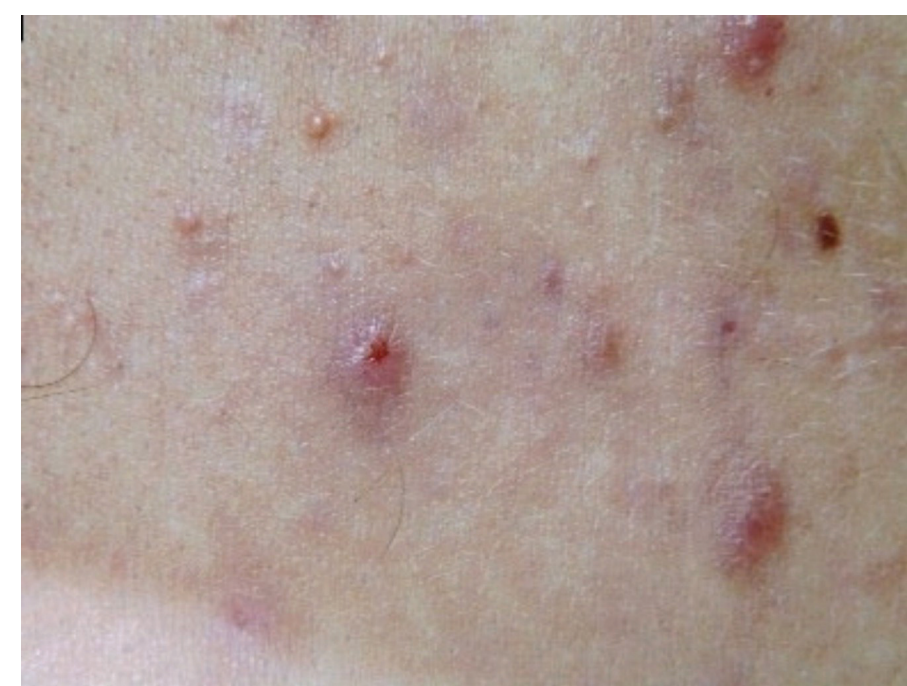

Fig. 8 - Detail of the erythematous papules, intensely itchy, located at the abdomen (area of contact with the surf board) of a male patient, at the fourth episode that occurred after surfing on the same beach (Balneário Camboriú, State of Santa Catarina).

Clinical Resolution: The timing of the clinical improvement was documented in 31 cases $(81.6 \%)$. Itching and skin lesions disappeared between two to 30 days, with an average of 7.6 days and a median of seven days. All patients showed good resolution.

\section{DISCUSSION}

In 1998 SILVEIRA \& MORANDINI published in the São Sebastião Channel (São Paulo State), the finding of polyps of L. unguiculata, including the demonstration that the planulae larvae are produced with great frequency, from the polyp, regardless of the occurrence of phase of jellyfish or Medusa, by a mechanism of non-sexuated reproduction ${ }^{24,25}$.

These new ecological conditions in the Brazilian coast alerted to the possibility of future clinical accidents with $L$. unguiculata there. In 2001 HADDAD Jr. et al. published the first five cases of SBE in Brazil, occurring in the Southeastern region in the state of Sao Paulo, in Ubatuba town, near the coastal city of San Sebastião Channel ${ }^{9}$. In 2001 and 2005 the presence of a living colony of polyps of $L$. unguiculata was reported by MORANDINI et al. in the Arvoredo Island Reserve, located in Florianopolis city in Santa Catarina State ${ }^{18}$. Although the agent of dermatitis was not identified in any of the locations of accidents in our study, these findings highlight the conditions in the Santa Catarina coast for possible exposure to $L$. unguiculata.

In 2007 ROSSETTO et al. reported six cases of SBE in the southern Brazil, on the beaches of Balneário Camboriú and Mariscal, located in central-northern coast of the Santa Catarina State at the distance of, respectively, 24.8 and 9.3 miles from the Arvoredo Island Reserve ${ }^{22}$. All six cases were included in this study, and the diagnosis of five of these cases was conducted in 2001 and represented $13.2 \%$ of total accidents.

The SBE accidents occurred in 12 different beaches, in a total of 64 local beaches. Six of 14 municipalities of the state region (centralnorthern coast) were involved. The dermatological consultations were made at a private medical clinic, located in the center of Balneário Camboriú town.

The majority of accidents occurred in the months of December (39.5\%) and January (36.7\%), during the peak season of summer, in a State where tourism is a major economic activity, with approximately two million tourists in $2007^{23}$. The occurrence of more than one episode of SBE in eight patients $(21.1 \%)$ and the reporting of one-third having seen other bathers with the same symptoms and $26.3 \%$ having seen jellyfish on the beaches probably indicates that the actual number of cases is much higher.

L. unguiculata are small, approximately $1.5 \mathrm{~cm}$ in diameter, and are generally identified when a large outbreak occurs.

Future studies covering a dermatological examination of bathers on the beaches suspected of SBE in the stations of spring and summer, mainly in the months with the largest numbers of accidents, December and January, could show a higher incidence of the disease and alert to the possibilities of epidemic outbreaks in the region.

SBE occurred primarily in young children $(60.5 \%)$ and surfers $(39.5 \%)$, suggesting a longer time of exposure in the sea water than the adults. In our study, the duration of water exposure ranged from one to eight hours with a median of 2.5 hours. These data corroborate with the prospective risk factors identified by KUMAR et al. in $1997^{13}$.

We observed that the time between the exposure until the clinical diagnosis of SBE ranged from one to fifteen days with a median of four days.

The systemic symptoms of dyspnea, malaise and sneezing occurred in three adults (7.9\%), which disagreed with the medical literature review that generally describe the symptoms in children ${ }^{13,22.29}$. In 1998 BURNETT \& BURNETT reported the presence of blurred vision in a female patient of 19 years of age one week after the accident with $L$. unguiculata $^{3}$. In none of our patients were observed visual changes.

The location of the lesions in the gluteal region was typical of cases of SBE, and in two patients, one male and one female, injuries also occurred in areas of the contour of bathing costumes.

In surfers, most common affected regions were the chest, abdomen, arms and thigh, thus the areas in contact with the surfboard. The pressure exerted against the body board surfing probably causes the activation of the nematocysts of the cnidarian ${ }^{29}$.

The presence of lesions in exposed areas, less frequently, also observed in this study, is caused by the adherence of planulae larvae in the hair or in the flexures areas ${ }^{9,22}$.

To complete the histopathological examination skin biopsies of two patients, both usual visitors of beaches where the accidents happened were realized after prolonged clinical activity, in a young surfer with four episodes of SBE prolonged development of 30 days and rebellious treatment with loratadine and desonida and in a patient of 60 years, tourist, with three episodes in an interval of 60 days.

In a study published by WONG et al. seventeen biopsies by 
ROSSETTO, A.L.; DELLATORRE, G.; SILVEIRA, F.L. \& HADDAD JÚNIOR, V. - Seabather's eruption: a clinical and epidemiological study of 38 cases in Santa Catarina State, Brazil. Rev. Inst. Med. trop. S. Paulo, 51(3): 169-175, 2009.

cutaneous punch did not show follicular involvement (except in a case of associated supurative folliculitis) or fragments of penetrating nematocysts, findings reported in accidents caused by other jellyfish ${ }^{29}$. The standard histopathology of SBE is similar to arthropods bites ${ }^{29}$. The two histopathological examinations, although unspecific, revealed the findings expected in the SBE, one of the cases compatible with prurigo. None of the histopathological examinations revealed fragments of penetrating nematocysts.

BURNETT et al. (1996) described that the history of atopy or previous episodes of SBE were not correlated with the antibodies titers ${ }^{5}$. KOKELJ et al. reported a case of an accident by cnidarian where, in addition to the humoral immunity, the cellular immunity could also be involved in immune response, fact confirmed by the positive patch test for antigens of Olindas sambaquiensis, a jellyfish belonging to the class Hydrozoa $^{12}$.

Due to unavailability of serological tests, the sera are stored for future laboratory tests. The results of these laboratory tests will assess the profile of humoral immunity against the antigen of Linuche unguiculata.

Regarding the established therapy, all patients had regression of injuries, with a median of seven days, except for one young surfer, with four episodes of SBE, which was refractory to treatment with loratadine and desonide, with 30 days of evolving, and required the use of an ampoule of deposit corticosteroid (betamethasone), administered intramuscularly to achieve the regression of the manifestations.

A 1977 prospective study in Florida (USA), involving 735 tourists from four different beaches, showed that the risk of SBE may be reduced if the bathers, once out of the water, take a shower devoid of swimwear with which they swimmed ${ }^{13}$. In the same study, the history of atopy, the type of swimwear and application of oils, creams or lotions before the sea exposure were not protective ${ }^{13}$.

Currently, lotions based on the protective mucus of clown fish (genus Amphiprion are commercially available in some countries and has proved to be effective in preventing accidents caused for some species of jellyfish, as Chryosaora fuscescens and Chiropsalmus quadrumanus, among others ${ }^{2,11}$. Therefore, it may be possible that the lotion also may be protective against $\mathrm{SBE}^{11}$. However, clinical trials proving their effectiveness against $L$. unguiculata are necessary.

The use of topical vinegar, a cheap method, effective and readily available in places of accidents, irreversibly disables the nematocysts of L. unguiculata, but only preventing future discharges, not acting effect on the toxins already discharged ${ }^{17,19,20,21}$.

A recent small clinical trial, published by TAYLOR in 2007, with five patients, showed that the use of hot water $\left(45^{\circ} \mathrm{C}\right)$ is more effective than vinegar in pain control after accidents caused by water-living species of Carybdea ${ }^{27}$. LOTEN et al. (2006) reported the use of hot water in the treatment of accidents caused by the Portuguese man-o'-war (Physalia physalis), suggesting that the mechanism of action would be the inactivation of toxins of these cnidarians ${ }^{15}$. Again, clinical trials are needed to prove the effectiveness against $L$. unguiculata induced SBE.

In conclusion, the cases of this study are typical in clinical and epidemiological aspects. The majority of cases began while sea bathing, the dermatitis was manifested by very pruritic, erythematous papules under the area of swimwear; most patients were under 16 years and surfers who had prolonged saltwater exposure.

The incidence of dermatitis in Brazil is probably underestimated because many victims do not go to hospitals or clinics for medical treatment. Moreover, awareness by health professionals of SBE and differentiating from swimmer's itch may be suboptimal. This study brings together a number of SBE cases in Santa Catarina State (central-northern coast) during the period of seven years, highlighting the increasing incidence of this disease and its clinical and therapeutic implications for physicians who serve in the coastal areas of Brazil.

\section{RESUMO}

\section{Prurido do traje de banho: estudo clínico e epidemiológico de 38 casos no Estado de Santa Catarina, Brasil}

Os Cnidários são animais marinhos que estão relacionados com uma variedade de acidentes acometendo banhistas em regiões litorâneas. A larva plânula da cifomedusa Linuche unguiculata (uma pequena água-viva) é o agente etiológico de uma dermatite pápulo-eritematosa, intensamente pruriginosa, denominada Prurido do Traje de Banho. Acomete principalmente áreas do corpo cobertas pelo traje de banho, após exposição à água do mar. Sua presença é freqüente nas águas do Caribe, Golfo do México e da Flórida (Estados Unidos), local onde foi descrita pela primeira vez. Os autores relatam uma série de casos de Prurido do Traje de Banho ocorridos no Estado de Santa Catarina (região do sul do Brasil), com ênfase em seus aspectos clínicos e epidemiológicos.

\section{ACKNOWLEDGMENTS}

To Prof. Luís Antônio de Oliveira Proença (Laboratory of Oceanography / Vale do Itajaí University/UNIVALI - Itajaí, SC), Charrid Resgalla Junior (Zooplancton and Marine Ecotoxicology / Vale do Itajaí University/UNIVALI - Itajaí, SC), Patrícia Rossetto Correa (School of Physiotherapy / Vale do Itajaí University/UNIVALI - Itajaí, SC), Dr Jamesson de Macedo Mora (Ex-resident of Internal Medicine / Marieta Konder Bornhausen Hospital / Itajaí, SC) for the collaboration as coauthors in the report of six cases of seabather's eruption; Prof. Dr. José Fillus Neto (Federal University of Paraná/UFPR - Curitiba, PR), Prof. Dr. Manoel Paes de Oliveira-Neto and Prof. Dr. Leonardo Quintella (both from Evandro Chagas Clinical Research Institute/IPEC, Fiocruz/Rio de Janeiro, RJ) for the collaboration in the histopathologic exams.

\section{REFERENCES}

1. BLACK, N.A.; SZMANT, A.M. \& TOMCHIK, R.S. - Planulae of the scyphomedusa Linuche unguiculata as a possible cause of seabather's eruption. Bull. Mar. Sci., 54: 955-960, 1994.

2. BOULWARE, D.R. - A randomized, controlled field trial for the prevention of jellyfish stings with a topical sting inhibitor. J. Travel Med., 13: 166-171, 2006.

3. BURNETT, H.W. \& BURNETT, J.W. - Prolonged blurred vision following coelenterate envenomation. Toxicon, 28: 731-733, 1990.

4. BURNETT, J.W.; CALTON, G.J. \& BURNETT, H.W. - Jellyfish envenomation syndromes. J. Amer. Acad. Derm., 14: 100-106, 1986. 


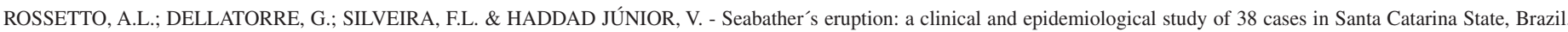
Rev. Inst. Med. trop. S. Paulo, 51(3): 169-175, 2009.

5. BURNETT, J.W.; KUMAR, S.; MALECKI, J.M. \& SZMANT, A.M. - The antibody response in seabather's eruption. Toxicon, 33: 99-104, 1995.

6. FREUDENTHAL, A.R. \& JOSEPH, P.R. - Seabather's eruption. New Engl. J. Med. 329: $542-544,1993$

7. GUIA SANTA CATARINA - Portal Turístico. Florianópolis, 2007. Available in http:// www.guiasantacatarina.com.br/. Accessed: 19 April 2008.

8. HADDAD Jr., V. - Atlas de animais aquáticos perigosos do Brasil: guia médico de identificação e tratamento. São Paulo, Editora Roca, 2000. p. 10-24.

9. HADDAD Jr., V.; CARDOSO, J.L.C. \& SILVEIRA, F.L. - Seabather's eruption: report of five cases in southeast region of Brazil. Rev. Inst. Med. trop. S. Paulo, 43: 171-172, 2001.

10. HADDAD Jr., V.; SILVEIRA, F.L.; CARDOSO, J.L.C. et al. - A report of 49 cases of cnidarians envenoming from southeastern Brazilian coastal waters. Toxicon, 40: 1445-1450, 2002.

11. KIMBALL, A.B.; ARAMBULA, K.Z.; STAUFFER, A.R. et al. - Efficacy of a jellyfish sting inhibitor in preventing jellyfish stings in normal volunteers. Wildern. environ. Med., 15: 102-108, 2004.

12. KOKELJ, F.; STINCO, G.; AVIAN, M.; MIANZAN, H. \& BURNETT, J.W. - Cellmediated sensitization to jellyfish antigens confirmed by positive patch test to Olindas sambaquiensis preparations. J. Amer. Acad. Derm., 33: 307-309, 1995

13. KUMAR, S.; HLADY, W.G. \& MALECKI, J.M. - Risk factors for seabather's eruption a prospective cohort study. Publ. Hlth Rep., 112: 59-62, 1997.

14. LITORAL DE SANTA CATARINA.COM. - Portal Turístico. Florianópolis, 2006 Available in: < http://www.litoraldesantacatarina.com/>. Accessed: 19 April 2008.

15. LOTEN, C.; STOKES, B.; WORSLEY, D. et al. - A randomized controlled trial of hot water $\left(45^{\circ} \mathrm{C}\right)$ immersion versus ice packs for pain relief in bluebottle stings. Med. J. Aust., 184: 329-333, 2006

16. MACSWEEN, R.M. \& WILLIAMS, H.C. - Seabather's eruption: a case of Caribbean itch. BMJ, 312: 957-958, 1996.

17. MIANZAN, H.W.; FENNER, P.J.; CORNELIUS, P.F.S. \& RAMIRES, F.C. - Vinegar as a disarming agent to prevent further discharge of the nematocysts of the stinging hydromedusa Olindias sambaquiensis. Cutis, 68: 45-48, 2001.
18. MORANDINI, A.C.; ASCHER, D.; STAMPAR, S.N. \& FERREIRA, J.F.V. - Cubozoa Scyphozoa (Cnidaria: Medusozoa) de águas costeiras do Brasil. Iheringia Ser. Zool. (Porto Alegre), 95: 281-294, 2005

19. PUERTAS, L.S.; LUTZ, L.L.; COTERA, E.H. \& BURNETT, J.W. - Eruption caused by a deep-sea cnidarians. Contact Dermatitis, 42: 280-281, 2000.

20. PUERTAS, L.S.; RAMOS, M.E.; ARAMBURO, C.; COTERA, E.P.H. \& BURNETT, J.W. - One Linuche mystery solved: all 3 stages of the coronate scyphomedusa Linuche unguiculata cause seabather's eruption. J. Amer. Acad. Derm., 44: 624-628, 2001

21. RESGALLA Jr, C.; GONÇALVES, V.G.C. \& KLEIN, A.H.F. - The occurrence of jellyfish stings on the Santa Catarina coast, southern Brazil. Braz. J. Oceanogr., 53: 183-186, 2005

22. ROSSETTO, A.L.; MORA, J.M.; CORREA, P.R. et al. - Prurido do traje do banho: relato de seis casos no Sul do Brasil. Rev. Soc. bras. Med. trop., 40: 78-81, 2007.

23. SANTUR. Santa Catarina Turismo S/A - Demanda Turística 2007. Florianópolis, 2008 Available in <http://www.sol.sc.gov.br/santur/>. Accessed: 19 April 2008.

24. SILVEIRA, F.L. \& MORANDINI, A.C. - Asexual reproduction in Linuche unguiculata (Swartz 1788) (Scyphozoa: Coronatae) by planuloid formation through strobilation and segmentation. Proc. Biol. Soc. Wash., 111: 781-794, 1998.

25. SILVEIRA, F.L. \& MORANDINI, A.C. - New observations on dormancy mechanisms in Linuche unguiculata (Swartz, 1788) (Scyphozoa: Coronatae). Bol. Mus. nac. Nova Sér. Zool. (Rio de J.), 393: 1-7, 1998

26. STUDDIFORD, J.S. \& BONAT, J. - Pruritic rash after an ocean swim. Amer. Fam. Physic., 76: 425-426, 2007.

27. TAYLOR, J.G. - Treatment of jellyfish stings. Med. J. Austr., 186: 43, 2007.

28. WILLIAMSON, J.A.; FENNER, P.J.; BURNETT, J.W. \& RIFKIN, J.E. - Venomous and poisonous marine animals: a medical and biological handbook. Brisbane, Queensland Surf life Saving; Kensington, University of New South Wales Press, 1996.

29. WONG, D.E.; MEINKING, T.L.; ROSEN, L.B. et al. - Seabather's eruption: clinical histologic, and immunologic features. J. Amer. Acad. Derm., 30: 399-406, 1994.

Received: 29 September 2008

Accepted: 12 March 2009 